\title{
ZBOCZE DOLINY WARTY W OKOLICACH UNIEJOWA
}

Zarys treści: Ważnym elementem doliny rzecznej są jej zbocza. To one nadają dolinie specyficzny charakter, decydują o atrakcyjności krajobrazu i wpływają na sposób zagospodarowania. Zbocza doliny Warty w okolicach Uniejowa są asymetryczne, przy czym wschodnie jest wysokie i strome, a miejscami porozcinane suchymi dolinami. W artykule przedstawiono zmienny charakter zbocza w odcinku o długości $14 \mathrm{~km}$, jego budowę geologiczną oraz genezę. Wskazano także jego oddziaływanie na warunki mikroklimatyczne (w tym siłę i kierunek wiatru lokalnego).

Słowa kluczowe: dolina Warty, zbocze doliny, Uniejów

\section{WPROWADZENIE}

Ważnym elementem doliny rzecznej są jej zbocza, czyli nachylone pod różnym kątem powierzchnie terenu rozciągające się między krawędzią doliny, a jej płaskim dnem. To one nadają dolinie specyficzny charakter, decydują o atrakcyjności krajobrazu, a czasem mają wpływ na lokalny klimat. Istotna jest nie tylko wysokość względna zbocza i jego nachylenie, ale także długość i ekspozycja. Szczególnie duże walory krajobrazowe posiada strome zbocze doliny współcześnie podcinane przez rzekę. Dolina Warty w okolicach Uniejowa jest szeroka, a jej zbocza są asymetryczne, przy czym wschodnie na odcinku około $5 \mathrm{~km}$ jest wysokie i strome. Celem artykułu jest analiza rzeźby prawostronnego zbocza doliny Warty w odcinku o długości $14 \mathrm{~km}$ w okolicach Uniejowa (w tym podcinanego przez rzekę) i jego budowy geologicznej. Rozważano przyczyny zróżnicowana rzeźby na tak małym

* Elżbieta Kobojek, dr hab., prof. nadzw. UŁ, Instytut Zagospodarowania Środowiska i Polityki Przestrzennej Uniwersytetu Łódzkiego, 90-142 Łódź, ul. Kopcińskiego 31, e-mail: elzbieta. kobojek@geo.uni.lodz.pl. 
odcinku. Wskazano wpływ stromego zbocza na warunki mikroklimatyczne. Przedstawiono także fragment podcinanego przez rzekę zbocza w Uniejowie na tle morfologii doliny środkowej Warty i innych tego typu stoków.

W pierwszym etapie pracy wykonano badania przeglądowe dotyczące charakteru zboczy doliny w środkowym odcinku Warty o długości $130 \mathrm{~km}$ od Krzeczowa do Koła. Analizowano mapy topograficzne w skali 1:10 000 w celu wskazania fragmentów zboczy współcześnie podcinanych przez rzekę. Następnie przeprowadzono obserwacje terenowe w 22 wytypowanych stanowiskach. Są to wyraźne, strome zbocza doliny o charakterze skarpy. W północnej części doliny środkowej Warty położony jest badany stok w okolicach Uniejowa. Dla tego odcinka o długości prawie $14 \mathrm{~km}$ przeprowadzono badania szczegółowe. Analizowano w terenie wysokość i profil zbocza, budowę geologiczną oraz rozcięcia erozyjne. Wykorzystano treści mapy topograficznej, Szczegółowej Mapy Geologicznej Polski w skali 1:50 000 arkusz Uniejów ${ }^{1}$ oraz ręczne sondy geologiczne do głębokości $2 \mathrm{~m}$. Analizowano także literaturę dotyczącą genezy i przekształceń stoków doliny środkowej Warty.

\section{ZBOCZE W UNIEJOWIE NA TLE MORFOLOGII DOLINY ŚRODKOWEJ WARTY}

Dolina środkowej Warty pod względem morfologicznym, od Krzeczowa do Koła, położona jest w obrębie Niziny Południowowielkopolskiej ${ }^{2}$. Rozcina ona głównie osady zlodowacenia stadium warty ${ }^{3}$ i ma wyraźny południkowy kierunek (ryc. 1). W obrębie doliny środkowej Warty, można wyznaczyć trzy odcinki niższego rzędu: konopnicki (od Krzeczowa po Burzenin), sieradzki (od Burzenina po Uniejów) i kolski (od Uniejowa do Koła) ${ }^{4}$.

W odcinku konopnickim, na przemian występują przewężenia i rozszerzenia doliny. W odcinkach przewężeń, dolina jest zwykle wąską, symetryczną formą o stromych zboczach, a w odcinkach rozszerzeń jest asymetryczna, tzn. jedno zbocze jest strome, a drugie łagodne. Wskazać można dwa wyraźne zwężenia: pod Strobinem i w Burzeninie. Przy małej szerokości (do $1 \mathrm{~km}$ ), dolina ma głębokość 20-50 m. Należy jednak wspomnieć, że głębokość ta jest mierzona od kulminacji wysoczyzny do poziomu rzeki. W obu przypadkach forma dolinna ma cechy przełomu, co jest podkreślone rozcięciem pagórków typu kemowe$\mathrm{go}^{5}$. Z kolei rozszerzenia nawiązują do odcinków pradolinnych, a dolina osią-

1 J. Kamiński, J. Forysiak, Szczegółowa Mapa Geologiczna Polski w skali 1:50 000, arkusz Uniejów (588). PIG, Warszawa 2008.

2 J. Kondracki, Geografia regionalna Polski, Wyd. Naukowe PWN, Warszawa 1998.

3 T. Krzemiński, Geneza młodoplejstoceńskiej rzébby glacjalnej w dorzeczu środkowej Warty, „Acta Geogr. Lodz.” 1974, 33; J. Forysiak, Rozwój doliny Warty między Burzeninem i Dobrowem po zlodowaceniu warty, „Acta Geogr. Lodz.” 2005, 90.

4 T. Krzemiński, Burzenin - dolina Warty, [w:] Przewodnik wycieczki XIII Ogólnopolskiego Zjazdu PTG, Uniwersytet Łódzki, Łódź 1975a, s. 165-190.

5 T. Krzemiński, Burzenin - dolina Warty...; J. Forysiak, Rozwój doliny Warty... 
ga wtedy szerokość $6 \mathrm{~km}^{6}$. W odcinku konopnickim rzeka podcina stoki doliny w 18 miejscach, a średnia wysokość takiego zbocza wynosi 11,3 m. Najwyższa skarpa ukształtowana jest pod Strobinem, a jej wysokość sięga 20-18 m. Drugim co do wysokości jest zbocze podcinane przez Wartę w Krzeczowie 17-18 m, a trzecim w Konopnicy $15 \mathrm{~m}$. We wszystkich tych trzech przypadkach zbocza zbudowane są z gliny zwałowej. W Strobinie rzeka podcina wysoczyznę zbudowaną z gliny zwałowej, dodatkowo nadbudowaną przez pagórki strobińskie, które w sąsiedztwie doliny Warty buduje materiał morenowy w postaci niewarstwowanych żwirów i glin zwałowych ${ }^{7}$. Jedynie w Krzeczowie glina zwałowa przykryta jest cienką warstwa piasków i żwirów ablacyjnych ${ }^{8}$. Z kolei zbocze w Konopnicy zbudowane z gliny zwałowej jest dobrze przedstawione w literaturze, ponieważ powstało na nim osuwisko rotacyjne ${ }^{9}$.

W odcinku sieradzkim (od Burzenina do Uniejowa) dolina jest szeroka, od 4 do nawet $10 \mathrm{~km}$. W długich jej fragmentach stoki doliny są wysokie, ale znacznie oddalone od obecnego koryta rzecznego. Wyjątkowo wysoki stok występuje w Strońsku, ponieważ osiąga 27-30 m - jest to najwyższy stok w całym analizowanym środkowym odcinku doliny Warty. Zbudowany jest z gliny zwałowej, ale rzeka płynie środkiem dna doliny. Tylko w trzech miejscach zbocze doliny Warty w odcinku sieradzkim podcinane jest przez współczesną rzekę (nie analizowano żywego klifu nad Zbiornikiem Jeziorsko), a średnia wysokość skarpy wynosi $7 \mathrm{~m}$. Najwyższą wysokość, $11 \mathrm{~m}$, osiąga zbocze w Uniejowie. Jest to jednocześnie najwyższe zbocze podcinane obecnie przez rzekę w odcinku sieradzkim doliny Warty.

W odcinku kolskim, na północ od Uniejowa, dolina jest rozległa, ale płaska i nie ma już tak wysokich stoków. Miejscami trudno jest wyróżnić nawet poszczególne elementy doliny. Dopiero w samym Kole zbocze jest wyraźniejsze i ma $3 \mathrm{~m}$ wysokości. W okolicach Koła, Warta zmienia kierunek z południkowego na równoleżnikowy, a północne zbocze doliny jest ponownie wysokie i strome dopiero w okolicach Ochle (9 m), a w Pyzdrach osiąga nawet 15-20 m.

W całej dolinie środkowej Warty o długości $130 \mathrm{~km}$ zinwentaryzowano 22 wysokie zbocza podcinane współcześnie przez rzekę. Średnia wysokość takich zboczy maleje od 11,3 m w odcinku konopnickim, poprzez $7 \mathrm{~m}$ w odcinku sieradzkim, po $3 \mathrm{~m}$ w odcinku kolskim. Można stwierdzić, że we fragmentach doliny o małej szerokości, rzeka częściej podcina wysoczyznę zbudowaną z gliny zwałowej i kształtuje wysokie zbocza, nawet o charakterze skarp. Aż 82\% wszystkich analizowanych przypadków podcięć zostało zlokalizowane w przełomowych fragmentach doliny w odcinku konopnickim. Z kolei, w dolinie o dużej szerokości, nawet

6 T. Krzemiński (red.), Województwo łódzkie. Przewodnik, Wyd. Sport i Turystyka, Warszawa 1972.

7 T. Krzemiński, Mieścisko k. Konopnicy-pagórki strobińskie, stratygrafia neoplejstocenu, ewolucja rzeźby glacjalnej, bruzdy termoerozyjne, terasy doliny Warty, [w:] Przewodnik wycieczki XIII Ogólnopolskiego Zjazdu PTG, Uniwersytet Łódzki, Łódź 1975b, s. 199-206.

8 T. Krzemiński, Geneza młodoplejstoceńskiej...

9 J. Pietruszewski, Osuwisko w dolinie Warty pod Konopnica, „Acta Univ. Lodz., Folia Geogr." 1992,15 , s. 174-183. 
jeżeli jej stoki są bardzo wysokie np. w Strońsku, współczesna rzeka płynie zwykle środkiem równiny zalewowej i nie ma możliwości podcinania wysoczyzny. Dodatkowo w odcinku sieradzkim na wielu kilometrach rzeka jest obwałowana i w ten sposób także ustabilizowana. Należy podkreślić, że wszystkie najwyższe zbocza $(11-22 \mathrm{~m})$ podcinane przez rzekę zbudowane są z gliny zwałowej. Nieco niższe wysokość (3-5 m) mają zbocza w przypadku, gdy rzeka podcina wysoczyzny wodnolodowcowe lub starsze poziomy dolinne zbudowane w przewadze z piasków. Można stwierdzić także, że podcinane przez rzekę prawostronne zbocze w Uniejowie jest najbardziej na północ wysuniętym w całym odcinku środkowej Warty i jest dla niego typowe, tak pod względem wysokości, jaki i budowy geologicznej.

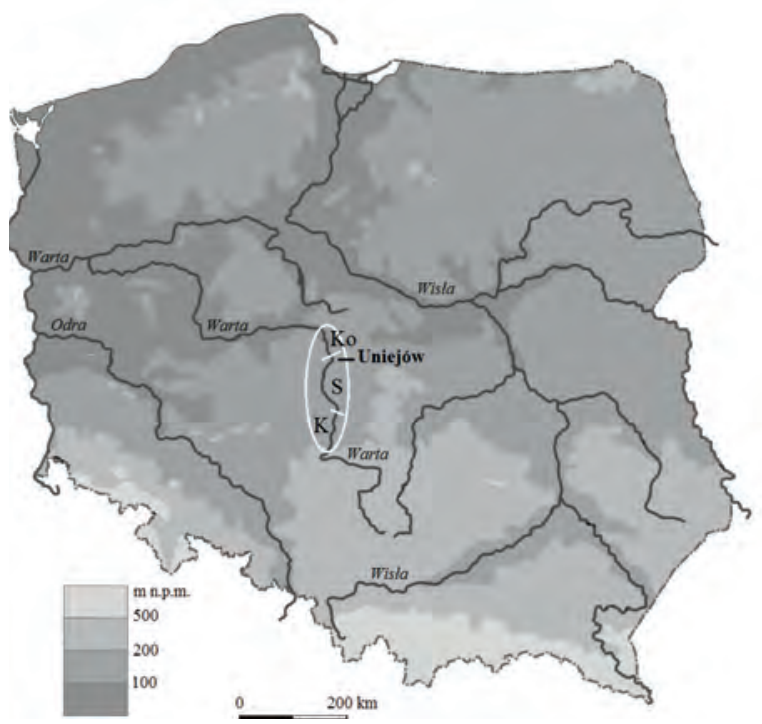

Ryc. 1. Położenie terenu badań przeglądowych w dolinie środkowej Warty (zaznaczony na biało)

i szczegółowych w Uniejowie. Objaśnienia oznaczeń na rycinie: $\mathrm{K}$ - odcinek konopnicki, od Krzeczowa do Burzenina, S - odcinek sieradzki, od Burzenina do Uniejowa, Ko - odcinek kolski, od Uniejowa do Koła Źródło: opracowanie własne

\section{RZEŹBA I BUDOWA GEOLOGICZNA ZBOCZA DOLINY W OKOLICACH UNIEJOWA}

Dolina Warty w okolicach Uniejowa jest szeroka (od 6 do $8 \mathrm{~km}$ ), a samo jej dno ma $2,5 \mathrm{~km}^{10}$. Jest także asymetryczna, ponieważ wschodnie zbocze o wysokości 11-7 m jest krótkie i bardziej strome, a zbocze zachodnie jest rozle-

${ }^{10}$ E. Kobojek, Krajobraz kulturowy doliny Warty w okolicach Uniejowa, „Biuletyn Uniejowski" 2016, t. 5, s. 175-191. 
glejsze i łagodniejsze. Jest to jednak sytuacja powszechnie spotykana w dużych dolinach o przebiegu południkowym w Polsce ${ }^{11}$.

W dalszej części analizowane jest tylko wschodnie (prawostronne) zbocze doliny Warty w odcinku uniejowskim o długości 14 km, od Dominikowic na południu po Ostrowsko na północy (ryc. 2). W Uniejowie rzeka podcina zbocze na odcinku o długości około 5,5 km (ryc. 3).

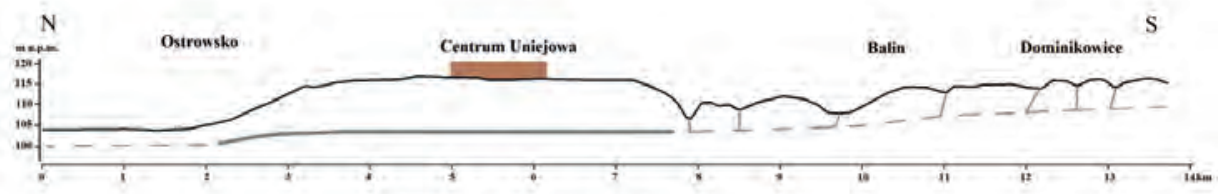

Ryc. 2. Profil hipsometryczny wzdłuż wschodniej krawędzi doliny Warty w okolicach Uniejowa, przewyższenie 50 -krotne

1 - linia profilu hipsometrycznego, 2 - odcinek doliny, w którym Warta podcina zbocze,

3 - odcinek doliny, w którym zbocze nie jest podcinane przez rzekę, 4 - cieki różnej wielkości rozcinające stok doliny

Źródło: opracowanie własne

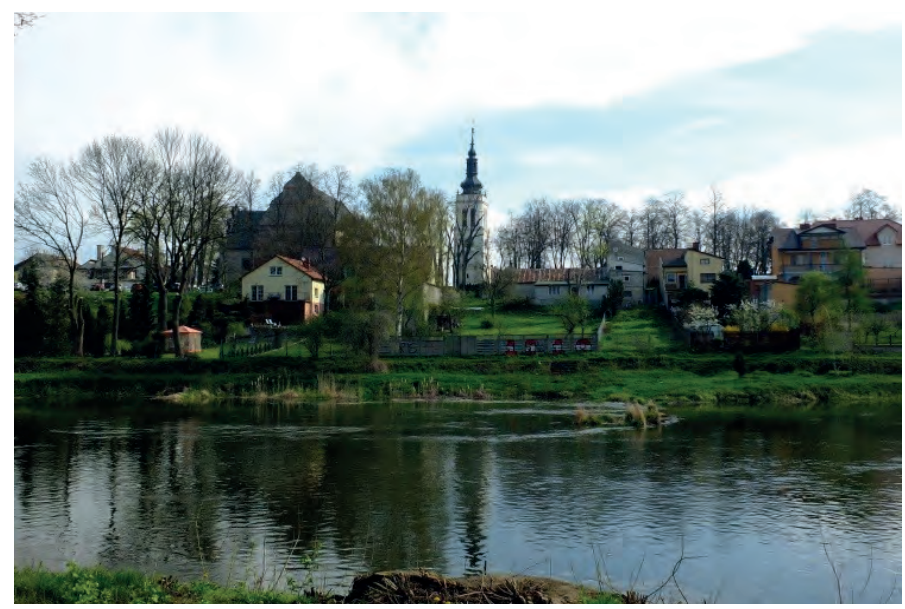

Ryc. 3. Zbocze doliny podcinane przez Wartę w Uniejowie

(fot. S. Kobojek, 2016)

W profilu analizowanego zbocza można wyróżnić trzy odmienne odcinki. Najbardziej charakterystycznym, wyrazistym i najwyższym jest fragment zbocza w samym Uniejowie. Jest to obszar wysoczyzny zbudowanej z gliny zwałowej stadiału warty, a podcinany przez Wartę, dlatego wykształciła się tutaj skarpa o wysokości $11 \mathrm{~m}$ (ryc. 4). Zbocze jest jednolite i zwarte na całej długości (ryc. 2). Górna krawędź zbocza położona jest na wysokości 115 m n.p.m.,

${ }^{11}$ M. Klimaszewski, Geomorfologia, PWN, Warszawa 1978. 
a podnóże na wysokości 103-104 m n.p.m. Stok jest krótki o nachyleniu w granicach $9-30^{\circ}$, przy czym są fragmenty bardziej strome. Jednak jego nachylenie w centrum Uniejowa zostało zmniejszone w wyniku nadsypywania i łagodzenia pod zabudowę usługową (ryc. 5). Z analizy profilu hipsometrycznego wynika, że można wskazać trzy typy stoków (ryc. 6). W miejscu bezpośredniego podcięcia przez rzekę stok ma profil złożony - w dolnej części jest bardziej stromy, a w górnej łagodniejszy. Jest to związane z erozją boczną rzeki, a ponieważ glina jest odporna na procesy erozji, dlatego dolna część stoku jest stroma. Generalnie przeważa tutaj profil wypukły, gdzie bardziej nachylony jest segment dolny. Pojawiają się także odcinki stoku o profilu wklęsłym (nachylenie rośnie wraz z wysokością), ale jest ono zwykle związane z działalnością człowieka zmierzającą do złagodzenia nachylenia. Im rzeka bardziej odsuwa się od stoku, tym staje się on bardziej wyrównany, prostoliniowy (nachylenie nie zmienia się wraz z wysokością). Taki profil świadczy o pewnym ustabilizowaniu stoku. Nie jest już od dołu podcinany przez rzekę, a procesy stokowe doprowadzily powierzchnię do kąta naturalnego spoczynku. Ważna jest także ekspozycja fragmentu stoku w Uniejowie - wystawiony jest on na południowy zachód.

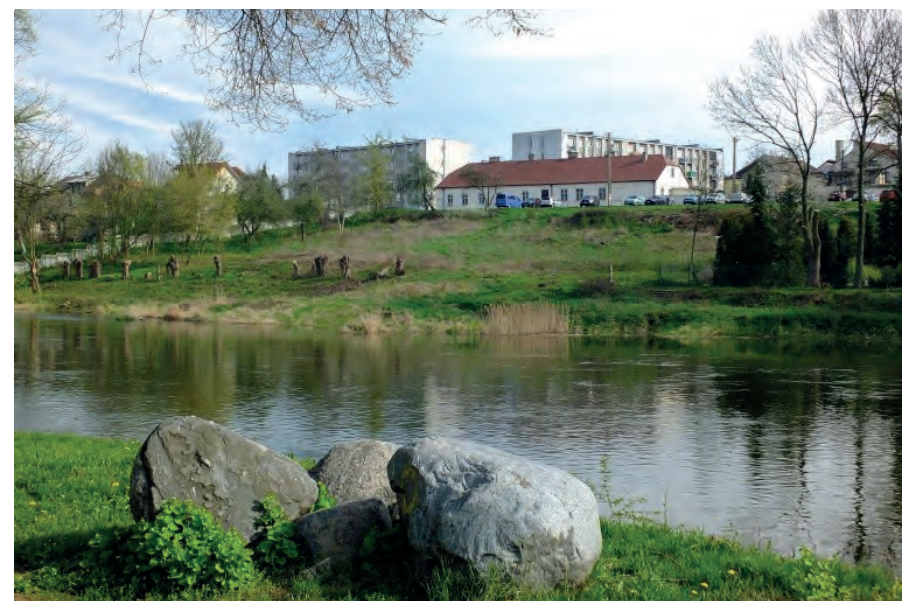

Ryc. 4. Zbocze doliny Warty zbudowane z gliny zwałowej i podcinane przez rzekę (fot. S. Kobojek, 2016)

Na południe od Uniejowa stok ma nieco inny przebieg - na długości prawie $6 \mathrm{~km}$ jest bardziej urozmaicony i poprzecinany formami erozyjnymi, miejscami dosyć głębokimi. Górna krawędź stoku położona jest na różnych wysokościach: w Dominikowicach osiąga 115 m n.p.m., a na północ od Balina jest nieco niższa $111 \mathrm{~m}$ n.p.m. (ryc. 2). Zbocze nie jest podcinane przez rzekę, która płynie w odległości około 200-600 m od jego podstawy (ryc. 6). Ten fragment stoku ma zmienną budowę geologiczną. W części południowej, stok wyższy i bardziej zwarty, zbudowany jest z gliny zwałowej miejscami przykrytej piaskami fluwioglacjalnymi, a w części niższej zbudowany jest tylko z utworów fluwioglacjal- 
nych (piaski i żwiry), bardziej podatnych na procesy erozyjne (ryc. 2). Stok ten porozcinany jest dolinami małych, często okresowych cieków, którymi woda płynie tylko po ulewnych deszczach, albo po roztopach. Dwie takie formy są większe i wyraźne, a obok niech są jeszcze cztery mniej zarysowane w terenie. Stok doliny jest $\mathrm{w}$ tym odcinku długi, ale łagodny o nachyleniu około $0,5^{\circ}-2,1^{\circ}$. Wysokość względna właściwie nie przekracza $5 \mathrm{~m}$. Podnóże łagodnie łączy się $\mathrm{z}$ dnem doliny, a fragment bardziej stromy związany jest zwykle z warstwą gliny zwałowej. Ten fragment stoku doliny ma ekspozycję zachodnią.

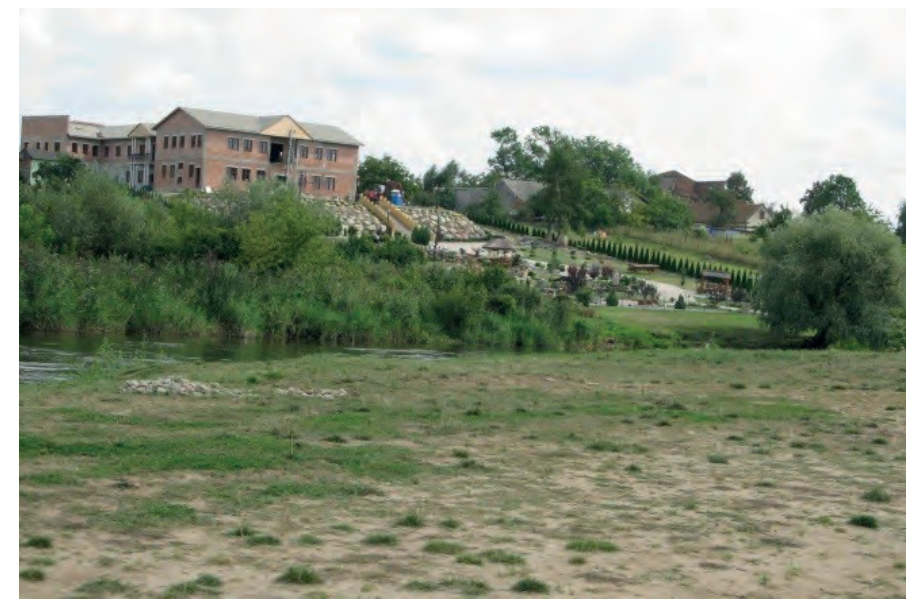

Ryc. 5. Zbocze doliny Warty łagodzone podczas prac budowlanych

(fot. E. Kobojek, 2016)

Zdecydowanie inną morfologię posiada fragment stoku na północ od Ostrowska. Górna krawędź doliny wyraźnie obniża się o około 10 m od wyższej powierzchni zbudowanej z gliny zwałowej w Uniejowie ku niższej zbudowanej z osadów fluwioglacjalnych. Powierzchnia położona na wysokości 104-105 m n.p.m. genetycznie jest już terasą akumulacyjną pradoliny Odry-Warty ${ }^{12}$. Brak tutaj wyraźnych zboczy doliny Warty, występują jedynie łagodne stoki o wysokości rzędu 2-3 m i nieznacznym nachyleniu.

\section{PRZYCZYNY ZRÓŻNICOWANIA PROFILU ZBOCZA I PROCESY DENUDACYJNE}

Dno doliny rzecznej kształtowane jest przez procesy fluwialne (korytowe i pozakorytowe), ale jej zbocza pozostają pod wpływem procesów stokowych (denudacyjnych). Procesy denudacyjne powodują generalnie odprowadzanie materiału zwietrzelinowego z górnej części stoku ku niższej i na dno doliny. Ta dzia-

${ }_{12}$ J. Kamiński, J. Forysiak, Szczegółowa Mapa... 
łalność prowadzi do cofania lub spłaszczania stoku, a także do zacierania granicy pomiędzy stokiem a dnem doliny ${ }^{13}$. Duży wpływy na przebieg procesów denudacyjnych ma odporność i ułożenie osadów budujących zbocza doliny ${ }^{14}$. Można wnioskować, że ukształtowanie zboczy doliny Warty w okolicach Uniejowa jest uwarunkowane procesami fluwialnymi oraz budową geologiczną wysoczyzny.

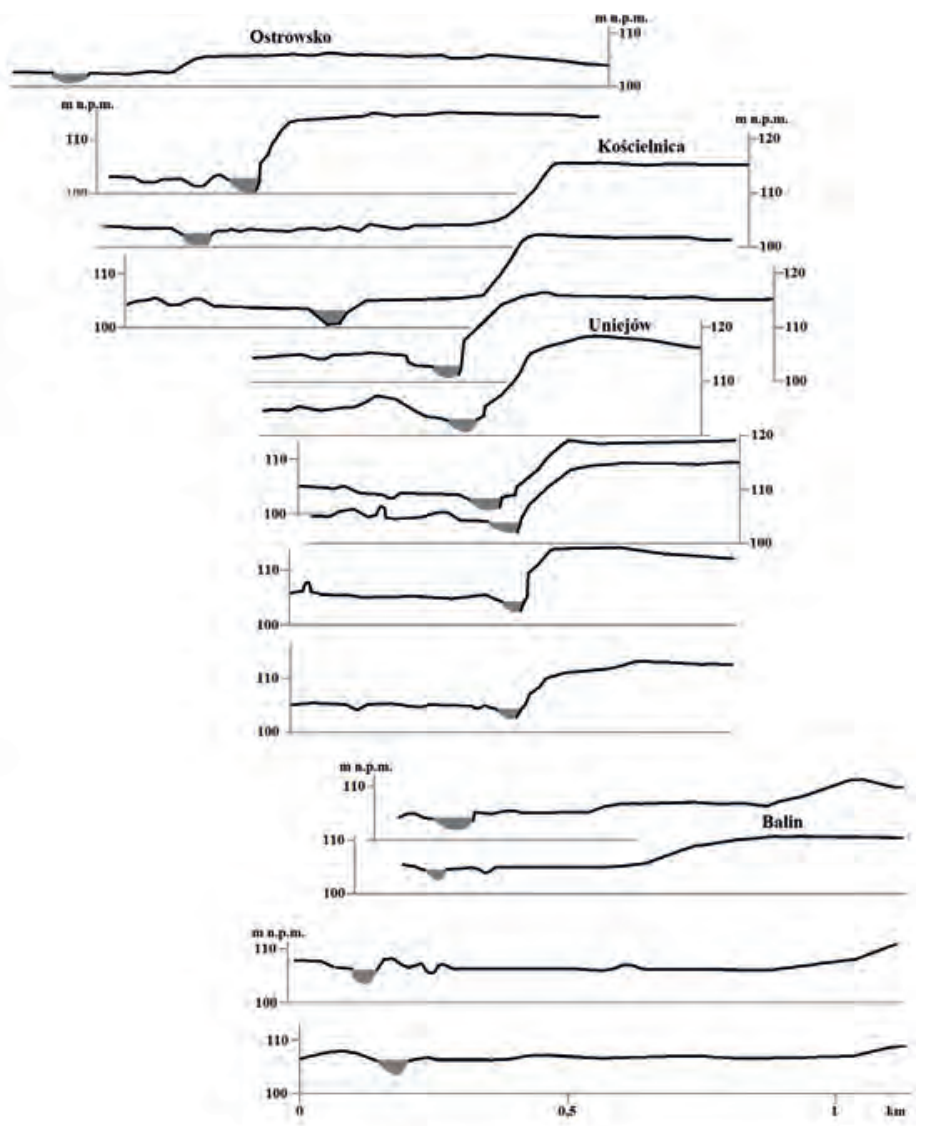

Ryc. 6. Profile hipsometryczne zbocza doliny Warty w okolicach Uniejowa Źródło: opracowanie własne

Warta, podobnie jak inne rzeki nizinne, płynąc w obrębie dna doliny zbliża się na przemian do lewego lub prawego brzegu. Częściej podcina jednak prawy brzeg i tworzy charakterystyczne skarpy. Duże rzeki nizinne na półkuli północnej częściej podcinają brzegi prawe, a spowodowane jest to ruchem wirowym Ziemi (spycha

${ }^{13}$ M. Klimaszewski, Geomorfologia, PWN, Warszawa 1987.

${ }^{14}$ E. Kobojek, Litologiczne uwarunkowania rozwoju wspótczesnych meandrów Rawki, [w:] Rekonstrukcja dynamiki procesów geomorfologicznych - formy rzeźby i osady, red. E. Smolska, D. Giriat, Wydział Geografi i Studiów Regionalnych, UW, Warszawa 2007, s. 260-267; J. Twardy, Przebieg holoceńskiej ewolucji stoków doliny Warty na obszarze poludniowej cześsi Kotliny Sieradzkiej w świetle analiz osadów stokowych, „Acta Geogr. Lodz.” 2004, 88, s. 49-84. 
on nurt pod jedno zbocze) i stałymi wiatrami zachodnimi w przypadku środkowej Polski ${ }^{15}$. W okolicach Uniejowa rzeka podcina właśnie wysoki, prawy brzeg.

Za strome zbocze w Uniejowie odpowiadać się wydają dwie przyczyny: proces erozji dennej i bocznej rzeki oraz duża odporność glin zwałowych na denudację. Erozja boczna rzeki doprowadza do zwiększenia stromości przydennych odcinków zboczy, co dobrze jest widoczne na niektórych profilach w Uniejowie (ryc. 6). Tempo erozji bocznej dla zboczy zbudowanych z gliny jest bardzo małe ${ }^{16}$, dlatego nachylenie jest duże, ale stabilne. Zbocza zachowują tę stromość tak długo, jak długo są podcinane przez wody rzeczne. Powstaje wówczas wyraźny załom między stromą częścią stoku, podcinaną stale lub okresowo przez wody rzeczne, a częścią o powolnym przebiegu procesów denudacyjnych, dla których bazą lokalną jest ów cofający się załom. Do naturalnych zagrożeń w dużych dolinach rzecznych w środkowej Polsce należą osuwiska ${ }^{17}$. Do warunków sprzyjających tym procesom stokowym należą strome zbocza zbudowane z gliny zwałowej podcinane przez rzekę. Chociaż w Uniejowie występują takie warunki, to jednak zagrożenie osuwiskowe jest nieznaczne. Jest tu krótki odcinek i jednak dosyć łagodny, dlatego ewentualne osuwisko byłoby małe.

Inaczej kształtowany jest stok na południe od Uniejowa zbudowany z utworów fluwioglacjalnych i nie podcinany obecnie przez Wartę. Utwory te są bardziej podatne na procesy denudacji (spłukiwanie, spełzywanie), dlatego stoki z nich zbudowane są zwykle łagodniejsze. Dodatkowo stoki o ekspozycji zachodniej i południowo-zachodniej otrzymują więcej opadów i są przez deszcz silniej bombardowane aniżeli zbocza przeciwne, wystawione na suche wiatry wschodnie. Są też intensywniej niszczone przez wody roztopowe, ale okres niszczenia nie jest długi. U podnóża tego łagodnego stoku widoczny jest jeszcze załom, który powstał w wyniku podcinania przez wody powodziowe. W odcinkach dolinach, w których wody rzeczne nawet w czasie powodzi nie sięgają pod zbocza dolinne, materiał osuwający się i zmywany ze stoku gromadzi się u ich podnóży. Prowadzi to do zaniku załomu pomiędzy dnem doliny a zboczem - stok doliny przechodzi łagodnie w płaskie dno.

Dodatkowo zbocze porozcinane jest przez równoleżnikowe małe formy dolinne. Dna tych dolinek są zwykle zajęte przez łąki (tzw. łąki smużne zajmujące wilgotne obniżenia wśród pól), a nadmiar wód odprowadzają rowy melioracyjne. Przy utrudnionym odpływie są one nieraz zbyt mokre, a nawet zatorfione.

Rozcięcie zbocza doliny Warty zbudowanego z osadów fluwioglacjalnych przez formy erozyjne różnej wielkości jest zjawiskiem dosyć powszechnym. Już w latach 50. XX w. wyróżniono i opisano systemy niecek korazyjnych i suchych

${ }^{15}$ M. Klimaszewski, Geomorfologia...

${ }^{16}$ E. Kobojek, Litologiczne uwarunkowania...

${ }^{17}$ D. Ilcewicz-Stefaniuk, M. Lemberger, J. Magiera, S. Rybicki, T. Słomka, M. Stefaniuk, Cataloguing natural geological hazards over Poland's territory, "Pol. Geolog. Inst. Special Papers" 2004, 15, s. 53-60. 
dolin, nacinających zbocze na południe od Uniejowa ${ }^{18}$. Wnioskowano, że formy te mogły powstać w bardziej łagodnym pluwialnym klimacie. Zbocza doliny porozcinane zostały dolinami denudacyjnymi głównie w vistulianie. Na początku holocenu do wcinających się den dolinnych nawiązywały boczne rozcięcia, które dały początek współczesnym parowom. Krawędzie doliny Warty urozmaicone są licznymi dolinami i nieckami także w okolicach Burzenina, Strońska, Siedlątkowa $^{19}$. Za najważniejsze procesy morfogenetyczne modelujące stoki Warty w holocenie należy uznać spłukiwanie rozproszone i skoncentrowane. Od średniowiecza większego znaczenia nabrała lokalnie denudacja agrotechniczna, polegająca na grawitacyjnym przemieszczaniu w dół stoku wierzchnich poziomów glebowych podczas uprawy ziemi. W osiach suchych dolin powstały wtedy rozcięcia.

\section{MIKROKLIMAT ZBOCZA DOLINY}

Ponieważ w okolicach Uniejowa nie funkcjonuje stacja meteorologiczna, dlatego przy charakterystyce warunków klimatycznych miasta analizowane są dane ze stacji IMGW położonych w Kole i Kaliszu ${ }^{20}$. Zwykle pomijany jest wpływ lokalnej rzeźby, w tym przypadku dużej doliny rzecznej o przebiegu południkowym i zboczy o ekspozycji zachodniej i południowo-zachodniej. Dla obszarów wyżynnych, czy górskich wpływ zboczy na warunki klimatyczne jest oczywisty ${ }^{21}$. Można jednak przypuszczać, że zbocze doliny Warty także posiada specyficzny mikroklimat.

Hipsometria terenu ma duży wpływ na warunki mikroklimatyczne. Latem podczas dnia, powietrze nad zboczami nagrzewa się silniej niż powietrze zalegające w wilgotnej dolinie, dlatego przepływa ono od doliny ku zboczom. Najbardziej charakterystycznym zjawiskiem mikroklimatycznym związanym $\mathrm{z}$ orografią są warunki zagłębień terenowych. W nocy w dnach dużych dolin jest chłodniej niż na stokach. Najchłodniejsze powietrze zalega na dnie doliny, na zboczach temperatura jest wyższa i na płaskich okalających dolinę powierzchniach znowu jest niższa. Stąd pochodzi tzw. ciepła strefa skłonów, która w agrometeorologii stanowi teren uprzywilejowany dla roślinności, szczególnie podczas okresów przymrozkowych. Na wschodnich zboczach doliny Warty (o ekspozycji zachodniej) rozwinęła się roślinność kserotermiczna ${ }^{22}$. Na stoku

18 J. Dylik, O peryglacjalnym charakterze rzeźby środkowej Polski, „Acta Geogr. Lodz.” 1953, 4.

19 J. Twardy, Przebieg holoceńskiej ewolucji stoków doliny Warty na obszarze poludniowej części Kotliny Sieradzkiej w świetle analiz osadów stokowych, „Acta Geogr. Lodz.” 2004, 88, s. 49-84; J. Twardy, Transformacja rzeźby centralnej części Polski Środkowej w warunkach antropopresji, Wyd. UŁ, Łódź 2008.

${ }^{20}$ K. Błażejczyk, J. Szmyd, A.B. Adamczyk, Ogólne cechy potencjału leczniczego klimatu i bioklimatu Uniejowa, „Biuletyn Uniejowski” 2013, t. 1, s. 43-61.

${ }^{21}$ M. Molga, Meteorologia rolnicza, Państwowe Wyd. Rolnicze i Leśne, Warszawa 1970.

${ }^{22}$ R. Olaczek, Roślinność kserotermiczna okolic Działoszyna i doliny środkowej Warty, cz. 1, ZNUŁ, 1968, ser. II, 28. 
doliny w wielu miejscach występuje zespół roślinności ruderalnej (zespół popłochu pospolitego), który wykształca się na siedliskach ciepłych i suchych oraz wysoko nawożonych ${ }^{23}$.

W lecie wskutek silniejszego nagrzewania zboczy południowych i zachodnich, temperatura gruntu jest na nich wyższa od temperatury gruntu na terenach sąsiednich. Gleba na zboczach południowych i zachodnich wysycha łatwiej, w konsekwencji czego warunki mikroklimatyczne są łagodniejsze i inne niż zboczy północnych. Najcieplejsze obszary (warstwy przygruntowe) w zimie, wiosną i jesienią znajdują się właśnie na skłonach południowo-zachodnich. Dlatego zbocza doliny Warty o ekspozycji zachodniej i południowo-zachodniej są cieplejsze i suchsze.

Kierunki wiatru w środkowej części Polski uwarunkowane są głównie warunkami cyrkulacyjnymi, ale w pewnym stopniu lokalnym ukształtowaniem powierzchni terenu. W okolicy Uniejowa najczęściej występuje wiatr południowo-zachodni i zachodni - łącznie $36,1 \%{ }^{24}$. W Polsce środkowej wiatry zachodnie przeważają zimą (styczeń, luty), w kwietniu, a także latem (czerwiec, lipiec i sierpień $)^{25}$. Dolina Warty ma przebieg południkowy, a analizowane wysokie zbocza mają ekspozycję SW i W - czyli dowietrzną. Dlatego ruch powietrza z zachodu zbliżając się do dowietrznego, stromego zbocza doliny wznosi się po nim. Na stronie nawietrznej prędkość wiatru wzrasta wraz ze wzrostem wysokości zbocza. Takie warunki wietrzne wykorzystywano już w przeszłości, ponieważ w górnej części najwyższego i najbardziej stromego zbocza w Uniejowie pracowały aż cztery wiatraki ${ }^{26}$.

\section{PODSUMOWANIE}

Prawostronne zbocze doliny w Uniejowie jest najwyższym, podcinanym przez rzekę w północny fragmencie doliny środkowej Warty i typowym dla całego tego odcinka, tak pod względem wysokości, jaki i budowy geologicznej. Zwarty i jednolity profil zbocza w Uniejowie związany jest $\mathrm{z}$ jego budową geologiczną, czyli warstwą gliny zwałowej. Stok jest krótki o nachyleniu w granicach $9^{\circ}-30^{\circ}$. Z powodu dużej odporności zbocza zbudowanego z gliny zwałowej naturalne procesy denudacyjne zachodzą tutaj bardzo wolno, także erozja boczna rzeki jest minimalna. W samym mieście zbocze jest jednak łagodzone podczas prac budowlanych, głównie w wyniku terasowania i nadsypywania te-

${ }^{23}$ J.T. Siciński, A.U. Warcholińska, Roślinność synantropijna, [w:] Szata roślinna Polski środkowej, red. J.K. Kurowski, Towarzystwo Ochrony Krajobrazu, Wyd. EKO-GRAF, Łódź 2009, s. 135.

${ }^{24}$ K. Błażejczyk, J. Szmyd, A.B. Adamczyk, Ogólne cechy...

${ }^{25} \mathrm{M}$. Molga, Meteorologia rolnicza...

${ }^{26}$ F. Tomaszewski, B.M. Walczak, Młyny w gminie Uniejów - zakres problematyki historyczno-konserwatorskiej, „Biuletyn Uniejowski” 2017, t. 6. 
renu. Fragment stoku, na południe od Uniejowa, zbudowany z piasków i żwirów fluwioglacjalnych, jest bardziej urozmaicony. Porozcinany jest szeregiem drobnych cieków i suchych dolin. Stok doliny jest w tym odcinku długi, ale łagodny, o nachyleniu około $0,5^{\circ}-2,1^{\circ}$.

Ekspozycja zbocza doliny Warty w kierunku południowo zachodnim i zachodnim ma wpływa na jego mikroklimat. Zbocze jest cieplejsze, suchsze i bardziej wietrzne niż tereny sąsiednie.

\section{Bibliografia}

Błażejczyk K., Szmyd J., Adamczyk A.B., Ogólne cechy potencjału leczniczego klimatu i bioklimatu Uniejowa, „Biuletyn Uniejowski” 2013, t. 1.

Dylik J., O peryglacjalnym charakterze rzeźby środkowej Polski, „Acta Geogr. Lodz.” 1953, nr 4.

Forysiak J., Rozwój doliny Warty między Burzeninem i Dobrowem po zlodowaceniu warty, „Acta Geogr. Lodz." 2005, 90.

Ilcewicz-Stefaniuk D., Lemberger M., Magiera J., Rybicki S., Słomka T., Stefaniuk M., Cataloguing natural geological hazards over Poland's territory, „Pol. Geolog. Inst. Special Papers” 2004, 15.

Kamiński J., Forysiak J., Szczegółowa Mapa Geologiczna Polski w skali 1:50 000, arkusz Uniejów (588), PIG, Warszawa 2008.

Klimaszewski M., Geomorfologia, PWN, Warszawa 1978.

Kobojek E., Litologiczne uwarunkowania rozwoju współczesnych meandrów Rawki, [w:] Rekonstrukcja dynamiki procesów geomorfologicznych - formy rzeźby i osady, red. E. Smolska, D. Giriat, Wydz. Geogr. i Studiów Region., UW, Warszawa 2007, 260-267.

Kobojek E., Krajobraz kulturowy doliny Warty w okolicach Uniejowa, „Biuletyn Uniejowski” 2016, t. 5.

Kondracki J., Geografia regionalna Polski, Warszawa 1998, Wyd. Naukowe PWN.

Krzemiński T. (red.), Województwo łódzkie. Przewodnik, Wyd. Sport i Turystyka, Warszawa 1972.

Krzemiński T., Geneza młodoplejstoceńskiej rzeźby glacjalnej w dorzeczu środkowej Warty, „Acta Geogr. Lodz.” 1974, 33.

Krzemiński T., Burzenin - dolina Warty, [w:] Przewodnik wycieczki XIII Ogólnopolskiego Zjazdu PTG, Uniwersytet Łódzki, Łódź 1975a, s. 165-190.

Krzemiński T., Mieścisko k. Konopnicy - pagórki strobińskie, stratygrafia neoplejstocenu, ewolucja rzeźby glacjalnej, bruzdy termoerozyjne, terasy doliny Warty, [w:] Przewodnik wycieczki XIII Ogólnopolskiego Zjazdu PTG, Uniwersytet Łódzki, Łódź 1975b.

Molga M., Meteorologia rolnicza, Państwowe Wyd. Rolnicze i Leśne, Warszawa 1970.

Olaczek, Roślinność kserotermiczna okolic Dziatoszyna i doliny środkowej Warty, cz. 1, ZNUŁ 1968, ser. II, 28.

Pietruszewski J., Osuwisko $w$ dolinie Warty pod Konopnica, „Acta Univ. Lodz., Folia Geogr.” $1992,15$.

Siciński J.T., Warcholińska A.U., Roślinność synantropijna, [w:] Szata roślinna Polski środkowej, red. J.K. Kurowski, Towarzystwo Ochrony Krajobrazu, Wyd. EKO-GRAF, Łódź 2009.

Tomaszewski F., Walczak B.M., Młyny w gminie Uniejów - zakres problematyki historyczno-konserwatorskiej, „Biuletyn Uniejowski” 2017, t. 6. 
Twardy J., Przebieg holoceńskiej ewolucji stoków doliny Warty na obszarze południowej części Kotliny Sieradzkiej w świetle analiz osadów stokowych, „Acta Geogr. Lodz.” 2004, 88.

Twardy J., Transformacja rzeźby centralnej części Polski Środkowej w warunkach antropopresji, Wyd. UŁ, Łódź 2008.

[Artykuł wpłynął: maj 2017; akceptacja: czerwiec 2017]

\section{THE SLOPE OF THE WARTA RIVER VALLEY NEAR UNIEJÓW \\ Summary}

Slopes are an important element of a river valley. They determine the specific character of the valley and the attractiveness of its landscape, and influence the type of its development. The Warta valley slopes in the vicinity of Uniejów are asymmetric, with the eastern slope high and steep, at places cut with dry valleys. The article describes a section of the slope $13 \mathrm{~km}$ long, its origin and geological structure. It also explains its impact on the micro-climate (including the strength and direction of the wind).

Keywards: Warta river valley, slop of the valley, Uniejów 